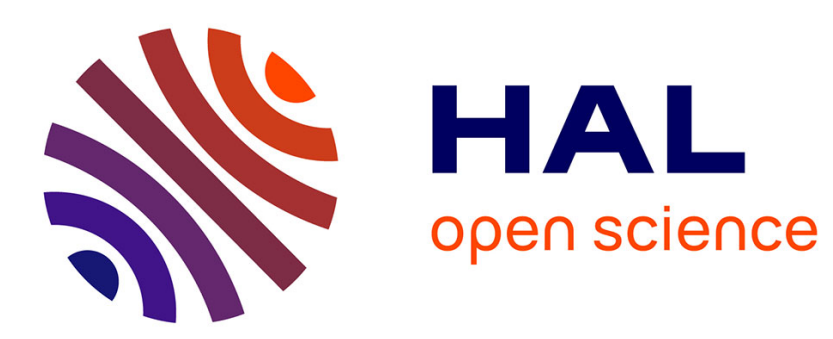

\title{
Why scientists with children who have disabilities need a different career trajectory
}

Olivier Pourret

\section{To cite this version:}

Olivier Pourret. Why scientists with children who have disabilities need a different career trajectory. Nature, 2020, 583, pp.646. 10.1038/d41586-020-02043-8 . hal-02893850

\section{HAL Id: hal-02893850 https://hal.science/hal-02893850}

Submitted on 8 Jul 2020

HAL is a multi-disciplinary open access archive for the deposit and dissemination of scientific research documents, whether they are published or not. The documents may come from teaching and research institutions in France or abroad, or from public or private research centers.
L'archive ouverte pluridisciplinaire HAL, est destinée au dépôt et à la diffusion de documents scientifiques de niveau recherche, publiés ou non, émanant des établissements d'enseignement et de recherche français ou étrangers, des laboratoires publics ou privés. 


\section{Why scientists with children who have disabilities need a different career trajectory}

Olivier Pourret

I've been deeply disturbed during lockdown by how many people seem to see washing their hands as a new thing. I haven't shaken hands with anyone for around five years. Other parts of lockdown and social-distancing measures feel familiar, too: I have not attended an international conference since 2014, for example. And I have not done any fieldwork for the past six years.

This is because one of my five-year-old twins has the rare genetic condition BeckwithWiedemann syndrome, which increases his risk of cancer. He was diagnosed with his first cancer at the age of five months. His immune system is still suppressed from the treatment he received when he was a small baby, and he is vulnerable to viruses or infections. The cancer treatment also made him deaf. To balance our family's work-life demands, my wife made a forced decision to take parental leave and put her career as a structural geologist on hold just after he was diagnosed.

I have taken several long periods of unscheduled leave (some of them without notice, in emergencies) from my academic job as a geochemist, spending these at hospital or at home with my son while he recovers.

This has taught me to be more productive in the time I do spend working at home and in the office, making each minute count, with no long coffee breaks. Time already spent networking 
online has helped me to work remotely, to build international collaborations and to stay connected to the scientific world without unnecessary air travel.

It is important that anyone assessing my career trajectory knows all this, and many organizations now take personal circumstances into account when considering promotions. But I do struggle with whether to mention aspects of my family life in other work situations, and still feel that my personal circumstances have counted against me professionally, especially when applying for big grants. However, my institution always recognizes my situation by giving me more consideration (including extra time off when I have to stay with my son for months).

Many scientists and administrators will have to change their processes now that the coronavirus has held everyone back in the same way. Most of us are currently unable to network at conferences, do laboratory work, work without distractions or even shake hands.

I hope, as we find new ways to measure each other's success in this new scientific world, that people with disabled children, as well as those in other disadvantaged academic groups, will be remembered long after lockdowns ease. 